\title{
Biomarker as an Indicator of River Water Quality Degradation
}

\author{
Dwina Roosmini ${ }^{1}$, Indah Rachmatiah ${ }^{1}$, Suharyanto $^{1}$, Agus Soedomo ${ }^{2}$ \& \\ Fajar Hadisantosa ${ }^{3}$ \\ ${ }^{1}$ Environmental Technology and Management Research Group, \\ Institut Teknologi Bandung, email: droosmini@bdg.centrin.net.id. \\ ${ }^{2}$ Surveying and Cadastre Research Group, Institut Teknologi Bandung \\ ${ }^{3}$ Environmental Engineering Master Program, Institut Teknologi Bandung
}

\begin{abstract}
Generally physical and chemical methods are use in river water quality monitoring; currently biomarker is developed as alternative biomonitoring method. The aim of this study is to look at the probability using aquatic species in monitoring river water pollutants exposure. This study was done by using Hyposarcus pardalis as biomarker to analyze river water quality in Upstream Citarum River. Hyposarcus pardalis were taken along the river at five sampling point and look at the $\mathrm{Cu}$ and $\mathrm{Zn}$ concentration. Results from this study show that there was an indication that river water quality has been degrading along the river from upstream to downstream. Zn concentration in Hyposarcus pardalis were increasing as well as $\mathrm{Cu}$ concentration. The increase of $\mathrm{Zn}$ concentration in Hyposarcus pardalis indicating that the river was polluted by $\mathrm{Zn}$. Secondary data and observation at sampling location shown that textile was the dominant industry which may contribute the $\mathrm{Zn}$ concentration in river as they received the effluent. $\mathrm{Cu}$ is use in metal coating process, as well as textile industry metal industries were identified at Majalaya, Bantar Panjang, Dayeuh Kolot and Katapang in Bandung-Indonesia. As a receiving water from many activities along the river, upstream Citarum River water quality become degrading as the increasing of heavy metal $\mathrm{Zn}$ and $\mathrm{Cu}$ concentration in Hyposarcus pardalis.
\end{abstract}

Keywords: biomarker; biomonitoring Hyposarcus pardalis; cooper; river; zinc.

\section{Introduction}

The increased environmental pollution due to human activities such as industrial and mining operation has encouraged the increase of metal in environment. The content of the metal in the environment has exceeded significantly the permissible level. The environmental health highly influences the public health, for which one of the essential way to maintain the environmental health is the integrated environmental management. Among the aspects of environmental management, monitoring of pollutant hazard in the environment is one of the important steps, which should be thoroughly considered.

Received April 2006, Revised September 29 ${ }^{\text {th }}$ 2006, Accepted for publication September $29^{\text {th }} 2006$. 
Biomarker as biochemical and physiological indicator of polluted environment can be applied to detect the impact of subleathel on particular species (fish). This can subsequently be used as an early warning of worse effect and pathological destruction. Besides this, biomarker is one of methods, which can be applied to monitor the environmental damage by measuring the pollution exposure on biota including human being. Some of the advantages of biological method in monitoring the environmental damages are measuring the real effect owing to environmental pollution and analizing the tendency of pollution historically, as well as measuring almost all effects from various pollutant sources.

The quality of most rivers or surface waters in West Java have decreased due to various pollutants from human activities. One of major rivers in West Java is Citarum River of which the cases of pollution at upstream level have been more frequently reported [5]. The quality of surface water in that river has been decreasing drastically. Along $127 \mathrm{~km}$ or $47.1 \%$ of the river's length has been heavily contaminated. In 1992, the pollution load from domestic was 55\%, industries 40\%, farming 5\% [5]. Presently, there are approximately 500 industries in Citarum watershed, out of which 400 industries located in the upstream level. The most dominant industry is textile, which is $74.5 \%$ and the rest of industries consist of food and beverage, metal, and pharmaceutical industry.

Table 1 Source and purpose of heavy metals in industry.

\begin{tabular}{lll}
\hline Industry & Heavy metal & Function \\
\hline Painting & $\mathrm{Hg}, \mathrm{Zn}, \mathrm{Pb}, \mathrm{Cr}, \mathrm{Cd}, \mathrm{Co}, \mathrm{Ni}$ & Raw material for painting \\
Textile & $\mathrm{Zn}, \mathrm{Pb}, \mathrm{Cr}, \mathrm{Cd}, \mathrm{Ni}$ & Raw material for painting \\
metal coating & $\mathrm{Zn}, \mathrm{Pb}, \mathrm{Cr}, \mathrm{Cu}, \mathrm{Ni}$ & Raw material for processing \\
pulp and paper & $\mathrm{Zn}, \mathrm{Pb}, \mathrm{Cd}$ & additive \\
Printing & $\mathrm{Pb}, \mathrm{Cd}$ & Raw material for tint/color \\
Rubber & $\mathrm{Cr}, \mathrm{Ni}, \mathrm{As}$ & Catalyst additive \\
Leather & $\mathrm{Zn}, \mathrm{Pb}, \mathrm{Cr}$ & additive \\
\hline Source: Djanarto, 1992 & &
\end{tabular}

As conservative and toxic pollutants, the existence of heavy metals in the water bodies should be limited to protect the public health. The concentration of heavy metals in Citarum River has been periodically monitored by various related agencies, such as the Water Research Centre, the Environmental Protection Agency, etc. Heavy metals could come out resulted from natural and human activities releasing heavy metal-containing wastewater. Some industries using heavy metals in their process can be seen in Table 1. 
Heavy metal is a metal with a specific gravity greater than about 5.0, especially one that is poisonous, such as lead or mercury (Miller, 1995). The atomic number is from 22 to 34 or 40 to 52 and is able to give a specific response biochemically to animals or plants. Heavy metal consists of 38 elements, which are widely used in industrial processes such as $\mathrm{Cd}, \mathrm{Mn}, \mathrm{Hg}, \mathrm{Cu}, \mathrm{Fe}, \mathrm{Ni}, \mathrm{Pb}, \mathrm{Zn}$. Typical of heavy metals producing a potential danger to human being, animals, and plants are $\mathrm{Cd}, \mathrm{Cu}, \mathrm{Hg}, \mathrm{Ni}, \mathrm{Pb}$, and $\mathrm{Zn}$.

The heavy metal concentration in natural water is relatively small in general. It frequently shows a number below $1 \mathrm{mg} / \mathrm{l}$ and is defined as trace metal. The presence of trace metal in natural water commonly is generated from industrial waste and or natural interaction between water and atmosphere in water bodies. A fluctuation of heavy metal concentration in water bodies is as a result from hydrodinamical, chemical, and biological adsorbing process. Chemical effect is mainly concerning with a variation of hydrogen ion concentration $(\mathrm{pH})$. The low $\mathrm{pH}$ indicates most metal ions are as free ions. Contrarily, at higher $\mathrm{pH}$, the ions are attached to hydroxide, carbonate, and sulphide, which is subsequently settled to the bottom. At $\mathrm{pH}$ of $8-11$, some metals settle down as hydroxide (Rouse, 1976).

Biomarker is often used to assess the impact of waste-producing activities polluting the environment and causing the biota's exposure (aquatic and terestrial) [6]. Biomarker is also a method to measure the level of biota's exposure to the pollutant. The biomarker of heavy metal has been developed to observe the human's exposure to Mn, Hg, and Pb. Mercury can be observed by analyzing its concentration in blood or urine. The measurement of $\mathrm{Hg}$ in urine is a suitable indicator for inorganic mercury. Meanwhile, the measurement of $\mathrm{Hg}$ in blood can represent the occurrence of exposure to organic mercury [1]. The use of biomarker for aquatic biota such as Elliptio complanata and Dreissena polymorpha has been conducted to observe the exposure and the impact of domestic waste discharge into river by Gagne [3]. The research conducted concerned with the analysis of metallothioneins (MT) and cytochrome P4501A1 activity.

Up to now, the study of biomarker method as river water quality monitoring in Indonesia has not been conducted. This study is the preliminary study of using biomarker in monitoring river water quality with the objective the prospect of Hyposarcus pardalis in biomarker method to identify the exposure of river water pollutan to aquatic biota. 


\section{$2 \quad$ Methodology}

This research is conducted from upstream to downstream parts of Citarum River. The aquatic animal used in this biomarker is Hyposarcus pardalis, which is present along the upstream level of Citarum river. $\mathrm{Cu}$ and $\mathrm{Zn}$ are selected as commond heavy metal pollutant identified in Citarum River. Method used to analyze the content of $\mathrm{Cu}$ and $\mathrm{Zn}$ in the fish is referred to SNI 06-2464-1991 (Indonesian National Standard) and USEPA 1991-d. The $\mathrm{Cu}$ and $\mathrm{Zn}$ are extracted from the fish tissue using Nitric Acid $\left(\mathrm{HNO}_{3}\right)$, dried in waterbath and anlayzed in Atomic Absorption Spectrophotometry (AAS). The locations for taking the fish as sampling points are based on the difference of landuse, in which distances are marked from upstream through downstream line. Five sampling points along the river are selected, based on distance from the upper point: (i) Majalaya, (ii) Bantar Panjang, (iii) Dayeuh Kolot, (iv) Katapang, and (v) Batujajar. For each point, nine fish are taken as samples, for which $\mathrm{Cu}$ and Zn content are analyzed. The content of both heavy metals subsequently are calculated to have an average value for each point. To determine the strength of (heavy metal) pollutant source at each point, the number and type of industries surrounding the sampling point are identified. Sampling points are described in Figure 1.

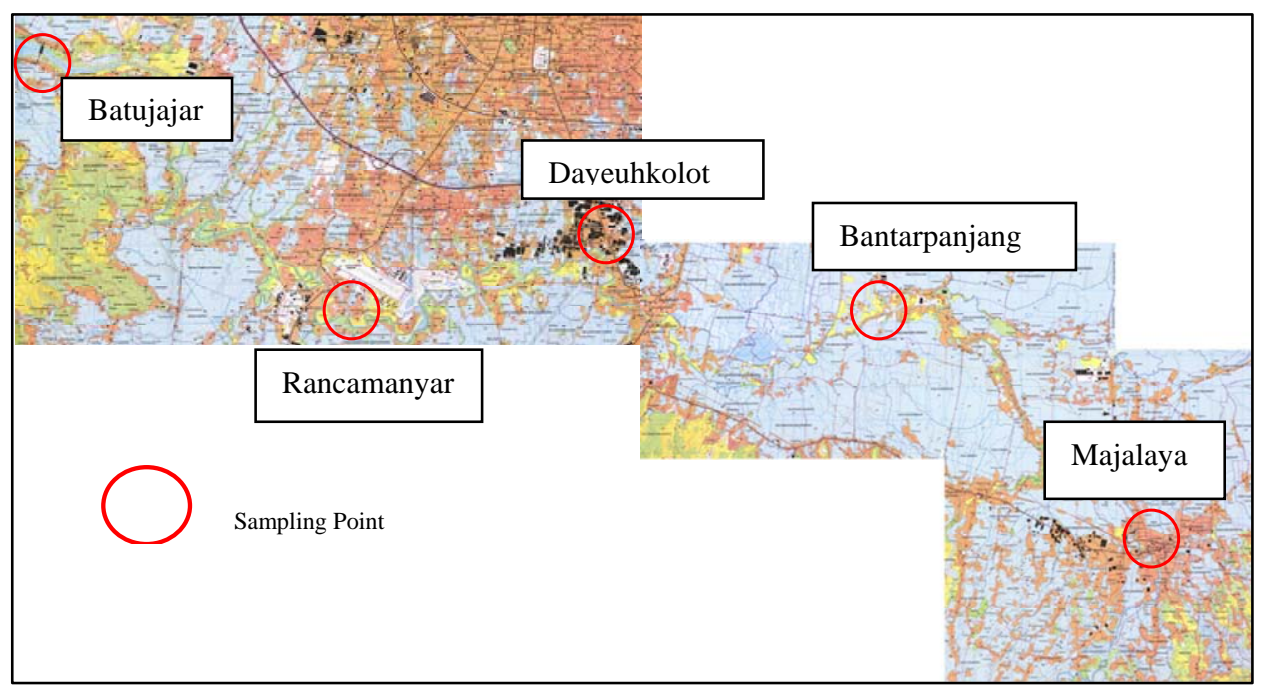

Figure 1 Map of sampling point.

\section{Results}

The type of industries located around the sampling points are shown in Figure 2. The figure indicates that the most dominant industry from upstream through 
downstream is textile, for which the largest number are located in Majalaya compared to any other sampling points. The Katapang sampling point has the smallest number of industries with the most variety of industries such as textile, washing, chemical, pharmaceutical, metal,pulp and paper, and leather industry. While there is only textile industry in Batujajar.

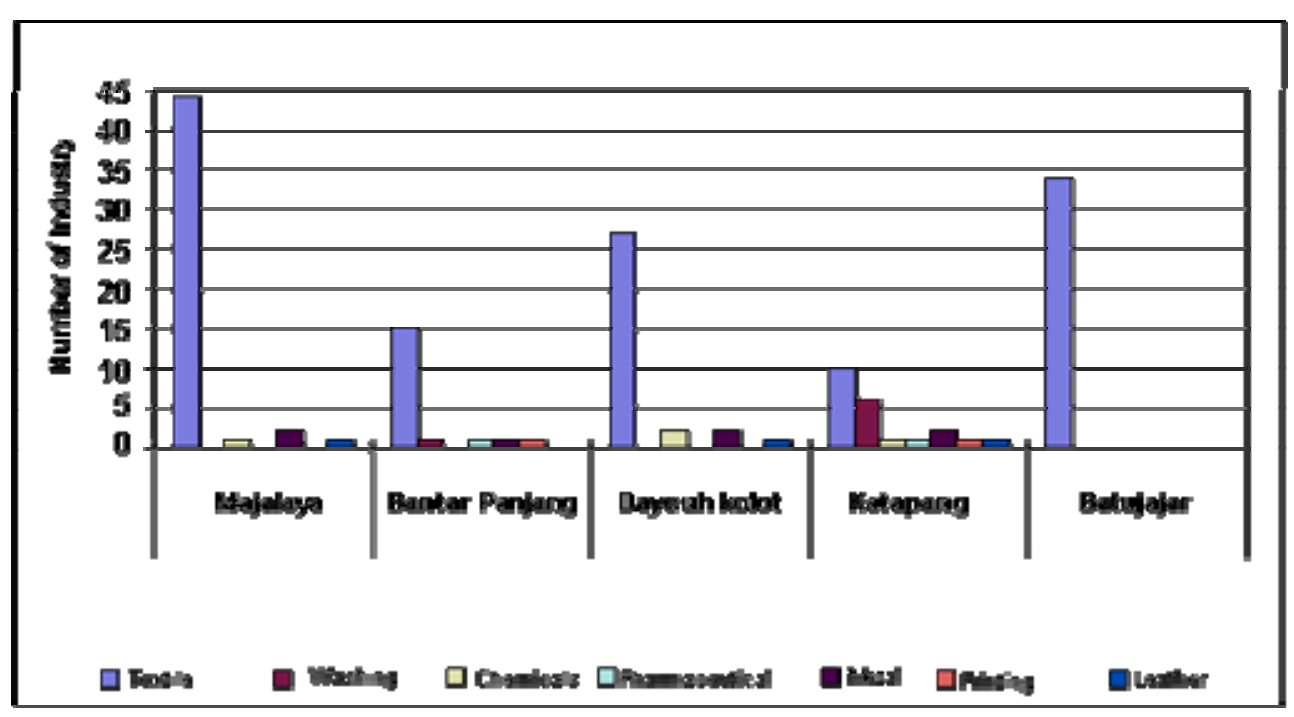

Figure 2 Composition of industries around the sampling locations.

Zinc (Zn) is heavy metal, which is produced by almost all type of industries: painting, metal coating, pulp and paper. Meanwhile, copper $(\mathrm{Cu})$ is generated by metal coating and mining industry. Metal coating industry producing both $\mathrm{Cu}$ and $\mathrm{Zn}$ is located in Majalaya, Bantar Panjang, Dayeuhkolot, and Katapang. Textile industry producing $\mathrm{Zn}$ is present in all location along upstream of Citarum river.

The content of $\mathrm{Zn}$ and $\mathrm{Cu}$ in (Hyposarcus pardalis) along the upstream of Citarum river is shown in Figure 3 and 4. The concentration of $\mathrm{Cu}$ is increasing from upstream through downstream with the value between 1.235 to $3.497 \mathrm{ppm}$ at Batujajar (downstream). Figure 3 indicates that the deviation standard at sampling point of Katapang and Dayeuhkolot is higher than that at other points. This could be possibly due to the variation of surface water condition at both points as shown in Figure 5, in which one side of the river has more concentrated colour than the other. Similar case also occurs for Zinc. 


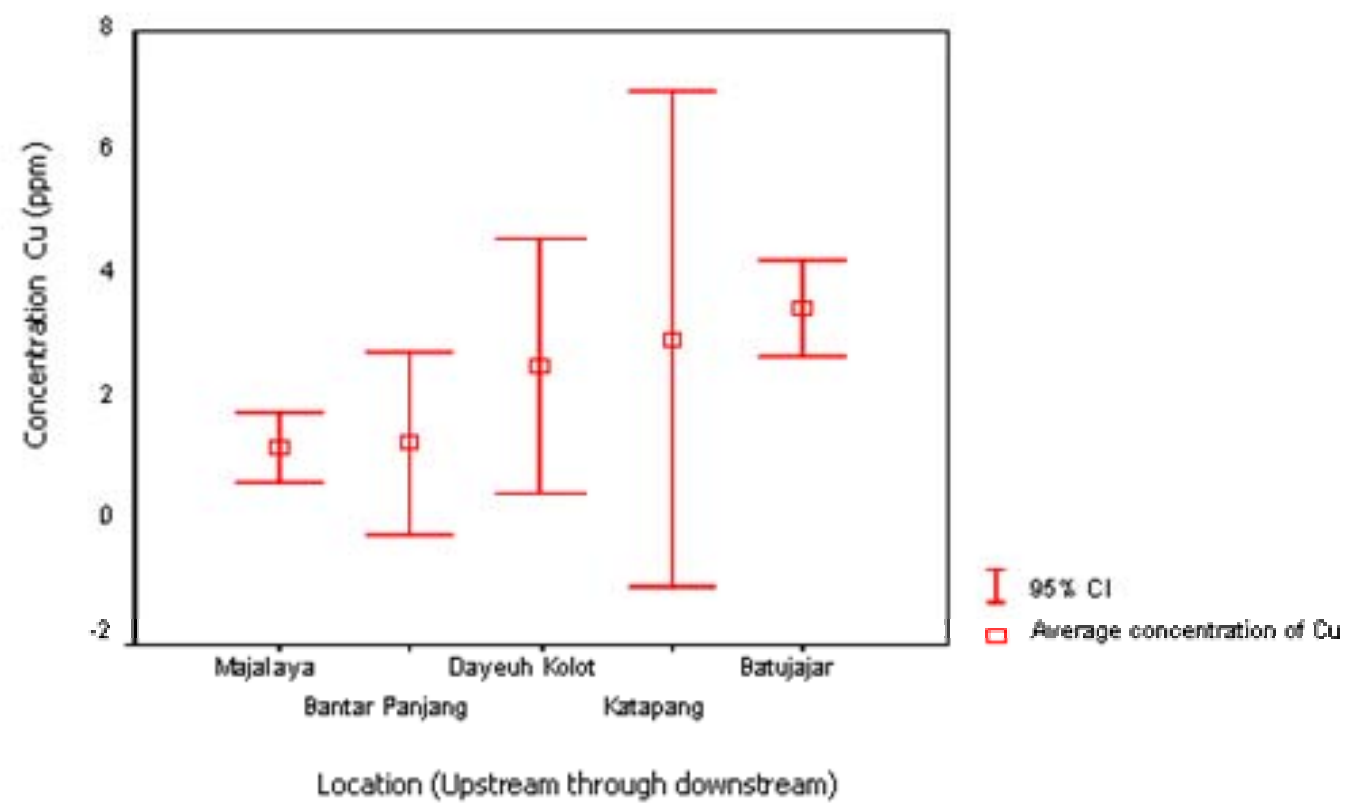

Figure $3 \mathrm{Cu}$ concentration in Hyposarcus pardalis at various points along the Citarum upstream.

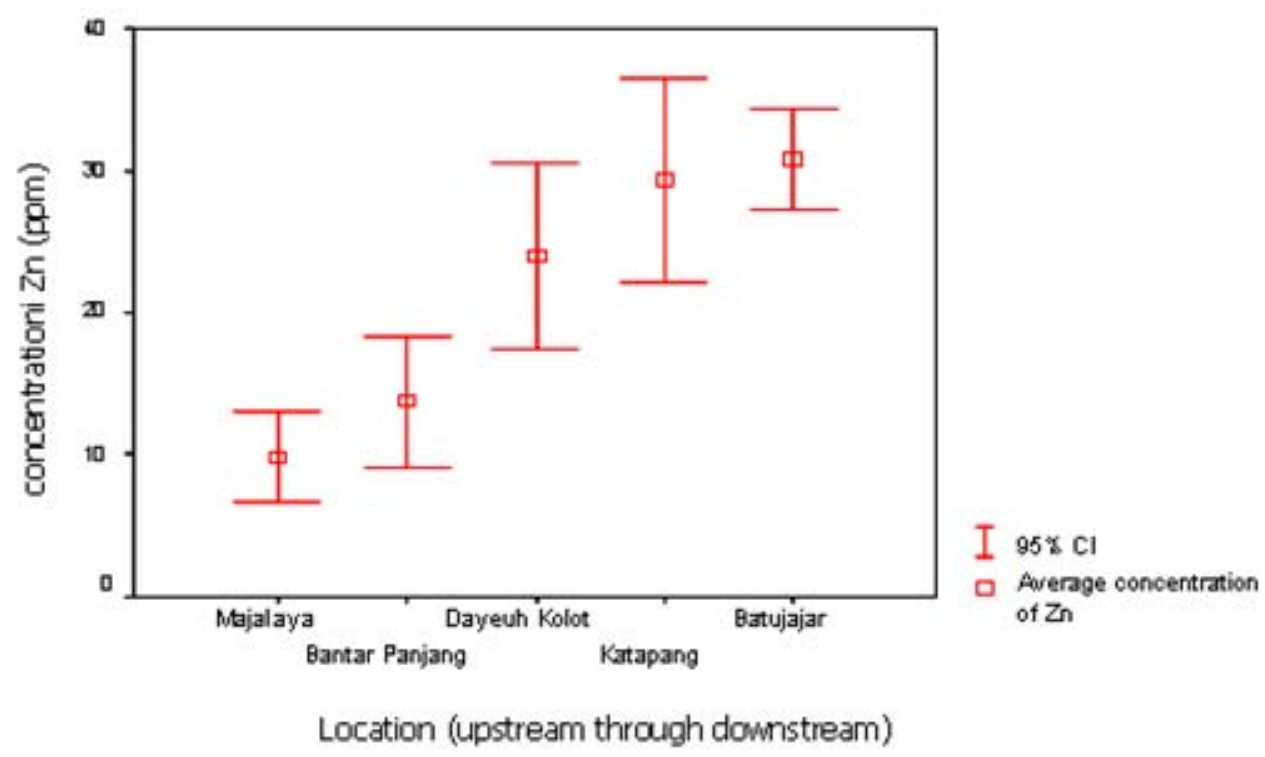

Figure 4 Zn concentration in Hyposarcus pardalis at various points along the Citarum upstream 
Similar to $\mathrm{Cu}$, the concentration of Zinc in the fish along the upstream of Citarum River seemingly increased up to 3 times higher, from $9.852 \mathrm{ppm}$ in Majalaya to 30.756 in Batujajar. The rising concentration of Zinc in the fish is in line with the presence of some industries surrounding the sampling location. Zinc can be released from various industries as it is shown in Table 1. The highest escalation of Zinc concentration occurs between Bantar Panjang and Dayeuhkolot, even though the number of industry in Bantar Panjang is less than that in Majalaya. Compare to $\mathrm{Cu}$, the increasing of $\mathrm{Zn}$ concentration in Hyposarcus pardalis are more significant along the river from upstream to downstream, these phenomenon showing that water quality along the has been degraded because of $\mathrm{Zn}$ pollution to the river.

As shown in Table 1, Zn are released from several type of industry (painting, textile and metal coating), even the number of textile industry are not increase from upstream to downstream (Figure 3), the concentration of $\mathrm{Zn}$ in Hyposarcus pardalis as biomarker indicating that the river water quality are decreasing to downstream. Other human activity along the river watershed should be identified related to $\mathrm{Zn}$ pollution.

$\mathrm{Cu}$ concentration in Hyposarcus pardalis are not as high as $\mathrm{Zn}, \mathrm{Cu}$ are more fluctuated along the river. $\mathrm{Cu}$ are use in metal coating industry which are identified in Majalaya, Bantar Panjang, Dayeuhkolot and Katapang sampling location.

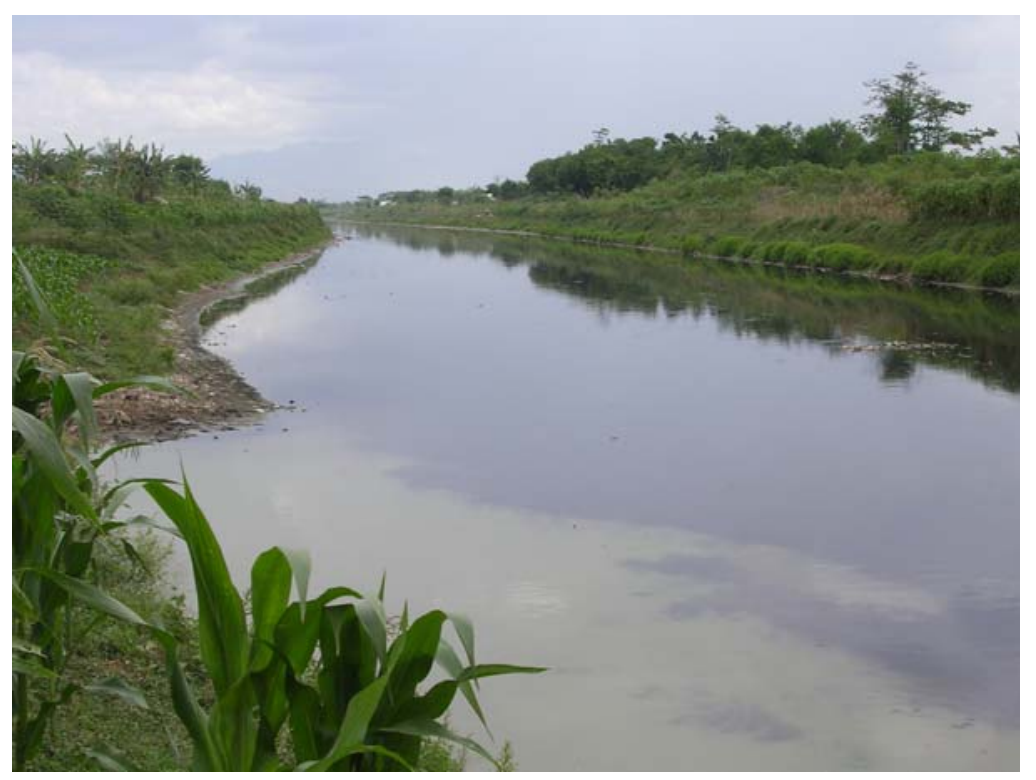

Figure 5 The situation of sampling point at Katapang. 


\section{Conclusion}

1. Water quality along the Upstream Citarum River are degrading as the increasing of $\mathrm{Zn}$ and $\mathrm{Cu}$ concentration in Hyposarcus pardalis as the biomarker.

2. Zn concentration in Hyposarcus pardalis increase from $9.852 \mathrm{ppm}$ in Majalaya to 30.756 in Batujajar.

3. $\mathrm{Cu}$ concentration in Hyposarcus pardalis increas from upstream through downstream with the value between 1.235 to $3.497 \mathrm{ppm}$ at Batujajar (downstream).

4. Identified industries around sampling location were textile (dominantly), metal coating and leather. These industries may contribute the heavy metal pollution to the river.

5. Biomarker using Hyposarcus pardalis are potential to be develop as alternative method in surface water quality monitoring method, the heavy metal concentration level in Hyposarcus pardalis are showing the significant exposure of heavy metal to aquatic organism.

\section{Acknowledgment}

This research is funded by ITB Research Grant no. 0076/K01.03/PL2.1.5/VI/ 2005.

\section{Reference}

[1] Autrup, H., in M. Ruchirawat \& R.C. Shank, Environmental Toxicology, Chulabhorn Research Institute, International Center for Environmental and Industrial Toxicology (1996).

[2] Stewart, P.A., in S.M. Rappaport \& Thomas J. Smith, Exposure Assessment for Epidemiology and Hazard Control, Lewis Publisher (1991).

[3] Gagne, et al., Biomarker Study of a Municipal Effluent Dispersion Plume in Two Species of Freshwater Mussels, Environmental Toxicology 17: 149-159 (2002).

[4] Djanarto, Monitoring Exposure B3 Angkatan II, Bapedal \& PPSDAL (1992).

[5] Wangsaatmaja, Setiawan, Dampak Konservasi Lahan Terhadap Rezim Aliran Air Permukaan Serta Kesehatan Lingkungan, Suatu Analisis Kasus DAS Citarum Hulu (The Impact of Land Conversion to Water Surface Regime and Environmental Health, a Case Study on Upper Citarum Watershed), PhD Dissertation, ITB (2004).

[6] Forbes, V.E., Forbes, T.E., Chapman \& Hall, Measuring Ecotoxicological Effects on Populations, Communities and Ecosystem, 
Ecotoxicology in Theory and Parctice, Springer-Verlag Berlin Heidelberg (1994). 